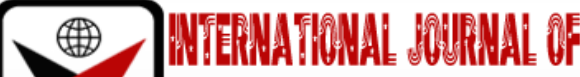

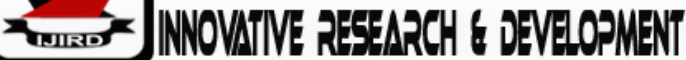

ISSN $2278-0211$ (Online)

\section{Intra-Specific Crosses in Tomato (SolanumLycopersicon L.) for Improvement of Fruit Quality: A Strategy for Enhanced Food Security}

\begin{tabular}{c} 
Gbadamosi, A. E. \\
Professor, Department of Plant Science and Biotechnology, \\
Adekunle Ajasin University, Akungba Akoko, Nigeria \\
Osekita, O.S. \\
Senior Lecturer, Department of Plant Science and Biotechnology, \\
Adekunle Ajasin University, Akungba Akoko, Nigeria \\
Ajayi, A.T. \\
Senior Lecturer, Department of Plant Science and Biotechnology, \\
Adekunle Ajasin University, Akungba Akoko, Nigeria \\
Ajileye, O.D. \\
Graduate, Department of Plant Science and Biotechnology, \\
Adekunle Ajasin University, Akungba Akoko, Nigeria \\
Okere, A. U. \\
Deputy Director, Department of Gene Bank, \\
National Center for Genetic Resources and Biotechnology, Ibadan, Nigeria \\
\hline
\end{tabular}

\begin{abstract}
:
Breeding programme on improvement of tomato fruits and seed production were conducted in the cropping seasons of 2017 and 2018 on three genotypes of tomatoes NG/AA/SEP/09/042, Akungba 1 and Akungba 2. Randomized complete block design replicated three times was adopted on seedlings raised in the nursery for $2-3$ weeks and transplanted at a spacing of $30 \mathrm{~cm} \times 60 \mathrm{~cm}$ within and between rows. Morphological and yield traits were measured and all cultural practices such as weeding, thinning, pest and disease control measures were carried out in order to ensure a disease-free condition and clean environment. At flowering stage, crosses were carried out on the genotypes and successful fruit set were monitored till maturity, ripen fruits were plucked and seeds extracted from the berry, airdried under ambient temperature of $27^{\circ} \mathrm{C}$ to $30^{\circ} \mathrm{C}$ and relative humidity of $60-70 \%$ for about $5-6$ days. Among crosses, the highest percentage fruit set of 77.04\% was obtained in BXC followed by CXB with 75.65\%; the lowest value of $66.67 \%$ was recorded in $A x C$. Aborted crosses were highest in CxA (31.58\%), followed by $A x B$ (29.31\%) while the lowest (24.04\%) was obtained in BxC. Except for the number of locules, quantitative traits were significantly different from one another; PCV was greater than GCV for all traits and highly significant positive correlation existed between number of fruits per plant and number of clusters per plant. Marketable fruit size and weight with beefsteak shape were obtained in $B x C$ and $A x C$ crosses.
\end{abstract}

Keywords: Crosspollination, segregation, genotypes, improvement

\section{Introduction}

Tomato (SolanumlycopersiconL.) is one of the most widely cultivated vegetable crops in Africa and all over the world (Peirce, 1987; Opena and Kyomo, 1990; Osekita and Ademiluyi, 2014). World tomato production in 2001 was about 103 million tons of fresh fruits on an estimated 3.9 million hectares of land. Hence, is ranked at the top of all fruits and vegetables as a source of vitamins and minerals in the U.S. (Stevens, 1974). It plays a major role in human nutrition, as an excellent source of phosphorous, iron, and vitamins A, B and C (Cobley and Steele, 1976, Varela et al., 2003 and Naika et al., 2005). It is relatively a short duration crop and gives a high yield, it is economically attractive and the area under cultivation is increasing (Naikaet al., 2005).It is a tropical day neutral plant and predominantly self- pollinated, but a certain percentage of cross pollination occurs(Shashikanth, 2010).Singh et al., (2002) observed high genetic variation in tomato for plant height, number of days to fruit set, number of fruit per cluster, number of clusters per plant, number of fruits per plant, fruit weight per plant and fruit yield per plant. The high genetic differences observed in the traits offer an opportunity for indirect selection for yield in tomatoes. Thus, genetic improvement of cultivated tomato for yield and quality can normally be achieved through selection of genotypes with desirable traits that may exist in nature or by hybridization. (Osekita and Ademiluyi, 2014). Plants vary in mating system from completely outcrossing to completely 
inbreeding (selfing). Tomato is an annual plant which can reach a height of over two meters (Joshi et al., 2004; Naikaet al., 2005), reports show that tomato plant with mean plant heights of $121.36 \mathrm{~cm}$ will enhance optimum productivity. Hence, height is among characters with high heritability as reported by (Singh et al., 2000; Mohanty, 2003; Veershetty, 2004) which can be used as selection criteria for fruit yield. Number of fruits per plant had been reported and range as follows; 27.33 to 64.67 (Kumar et al., 2006), 14 to 65 (Upadhyayet al., 2005), 8.08 to 41.56 (Joshi et al., 2004). Mean fruit number per plant had been reported to be 19.65 (Haydaret al., 2007), 43.09 (Kumar et al., 2006) and 33.20 by (Upadyyayet al., 2005). Average fruit weight ranges had also been reported by different scholars as follows 36.33 to $71.07 \mathrm{~g}$ (Veershetty, 2004), 16.13 to 95.7g (Joshi et al., 2004), 29.83 to 92.67g (Mohanty, 2003). There appears to be significant genetic variation for these traits in tomatoes. This is important because the breakthrough in crop improvement depends on the magnitude of genetic variability. Yield components have been used in analysing and identifying source of variation in yield, this can be exploited in the improvement of cultivars to give higher yields (Fiezet al., 1991). The breakthrough of any crop improvement programme depends on the presence of genetic differences and extent to which the desirable trait is heritable (Osekita and Ajayi, 2013). This phenomenon in breeding materials had been emphasized by Falconer (1960), in order to exercise critical selection pressure. Heritability in broad sense is the heritable variation which was estimated as a ratio of genotypic variance to the phenotypic variance and expressed as a percentage (Harsonet al., 1956). The heritability percentage was scored as low (0-30\%), moderate $(30-60 \%)$ and high (60\% and above) as stated by Robinson et al., (1949). High heritability has been reported in tomato by different workers in the following yield components, plant height (Veershetty, 2004; Arunkumar and Veeraragavathatham, 2005; Upadhyayet al., 2005). Number of fruits per cluster (Singh et al., 2000, Prashanth, 2003, Veershetty, 2004).Number of fruits per plant (Upadhyayet al., 2005; Kumar et al., 2006; Haydaret al., 2007). Average fruit weight (Prashanth, 2003; Mohanty, 2003; Arunkumar and Veeraragavathatham, 2005). Total fruit yield per plant (Parvinder Singh et al., 2002; Upadhyayet al., 2005; Haydaret al., 2007). High heritability reported by these workers clearly indicates the improvement of these traits in tomato can be obtained through simple selection. Other scholars had reported moderate to high heritability in tomato yield components. This has been reported in the following components; number of fruits per plant, average fruit weight and fruit yield (Sivaprasad, 2008). According to Sivaprasad, (2008), moderate to high heritability of these traits suggest that the environmental factors also play a key role in the expression of these traits. Hence, improvement of fruit yield with the complement of its component traits should not be based on simple selection but also on progeny tests. Low to moderate heritability observed for fruits per cluster is an indication of the influence of genotype by environment (G X E) interaction in the expression of this trait (Sivaprasad, 2008). The yield potential of tomato has been reported to range from 60 to 100 tons per hectare (Varela et al., 2003). Cramer and Wehner (1998) said a method that could be used to improve productivity would be that of indirect selection for traits that show high correlation coefficient with yield and at the same time possess high heritability. These traits are often referred to as yield components. These traits in tomatoes include; number of whole fruits per plant, number of branches per plant, number of nodes per branch, number of pistillate flowers, number of fruits per node and marketable or early yield. According to Lungu, (1978) the consideration of yield components in selection is based on the assumption that a strong correlation exists among yield and its components and that these component traits have higher heritability than yield itself. The aims of tomato breeding have been to increase yield and other important traits as well as removing other constraints/barriers which reduce yield. Yield increase is based on the elimination of limits to yields as well as direct selection for yield per se (Frankel, 1947). Yield is a product of a number of components. It is a product of traits like number of plants per unit area, weight of single fruit and plant height. The degree of association of these components to yield and among themselves is of considerable importance to crop breeders. Correlation analysis is an important tool in statistical analysis. Correlation between two variables is to evaluate the degree of association between two variables. The correlation can be negative or positive. Both negative and positive correlation coefficients are important in plant breeding as the two shows the strength of association between any two characters under study. Selection can be done based on the relationship of plant characters which can be used to improve plant yield. Correlation is important as it has been reported by (Rogler, 1954; Kneebone, 1956). In breeding work, knowledge of characters interrelationship among themselves is essential if selection for immediate improvement of the characters for the most part effective (Dewey and Lu, 1959). In tomato, positive correlation of component traits with fruit yield had been reported as follows; plant height with fruit yield per plant (Joshi et al., 2004; Singh et al., 2004; Prashanth, 2003). Number of fruits per plant with fruit yield per plant (Haydaret al., 2007; Kumar et al., 2006; Prashanth 2003). Average fruit weight with fruit yield per plant (Prashanth, 2003; Joshi et al., 2004). Yield is a complex unit associated with a number of components traits. It is the chief concern of the plant breeders globally and is the ultimate factor on which selection programmes are to be envisaged. All changes in yield must be accompanied by changes in one or more traits (Graffius, 1964), and this does not need to be expressed by changes in yield. This is due to varying degrees of positive and negative correlation that exist between yield and its components (Rani et al., 2008). Tomato flowers had been reported to grow up to $2 \mathrm{~cm}$ in diameter. Flowers are borne in inflorescences of between four to twelve flowers. Its six petals are yellow and up to $1 \mathrm{~cm}$ in length (Rice et al., 1990). Marimbe, (1995), reported that maturity period of tomatoes varieties differs. The period varies from 83 to 89 days. The crop reaches 50 percent maturity at 66 to 71 days (Nyirongo, 1995; Marimbe, 1995). Maturity period of Expresso (semi determinate) and Sixpack (determinate) had been reported to be 80 days after transplanting, it was also reported that the first harvest is possible 45 to 55 days after flowering, or 90 to 120 days after sowing (Naikaet al.,2005). This study was conducted to improve the quality of fruits through hybridization and optimal fruit yield.

\section{Materials and Methods}

Three high yielding accessions of tomato were obtained from Plant Breeding Unit of the department of Plant Science and Biotechnology, AdekunleAjasin University AkungbaAkoko. The tomato accessions are AKUNGBA 1, AKUNGBA 
2 and NG/AA/SEP/09/042.The experiment was carried out at the screen house in AdekunleAjasin University, AkungbaAkoko, Ondo State. Seedlings were raised in the nursery for 3 weeks, after which they were transplanted into polytene nylon filled with $5 \mathrm{~kg}$ sieved sandy loam soil in the screen house. The experiment was conducted via completely randomized design (CRD) replicated three times. Single seedling/bag was transplanted within and between rows adopting a spacing of $30 \mathrm{~cm} \times 45 \mathrm{~cm}$ respectively.

\subsection{Methodof Hybridization in Tomato}

Ten (10) pots were utilized per accession in two rows for reciprocal crosses. One seedling was planted per pot per accession and irrigated with $500 \mathrm{ml}$ of water every other day. Manual pollination of flowers was adopted between $6.30 \mathrm{am}$ and 8.30 am before the petals open. The flowers were opened with forceps to keep the pistil and stigma in view; emasculation was done to get rid of the anthers. Pollination by light dusting of pollens collected from newly exposed flowers of male parent on the exposed stigma of the female parent was done. All pollinated flowers were afterwards tagged and labelled with date and type of pollination. The duration of pollination continued until the plants were unable to produce flowers again.

\subsection{Collection of Data}

Data was collection on the following quantitative traits: plant height, number of branches, number of days to 50 percent flowering, number of days to first fruit set, number of fruits per plant, number of clusters per plant, number of fruits per cluster, average fruit weight, pericarp thickness, number of locules per fruit, number of flowers pollinated, number of fruits set after pollination, percentage of fruits set and number of days to maturity.

\subsection{Statistical Analysis of Collected Data}

The data was subjected to statistical analysis as described by Allard (1960). Analysis of Variance (ANOVA) was prepared separately for each character for the treatments.

\subsection{Estimation of Components of Varianc}

Genotypic and phenotypic variances was calculated according to the formulae provided by Lush (1940) for the observed traits.

\subsection{Coefficient of Variability}

Genotypic and phenotypic coefficients of variation were calculated according to Burton (1952).

The classification suggested for PVC and GCV by Shivassubramanian and Menon (1973) was adopted. Broad sense heritability was estimated as a ratio of genotypic variance to phenotypic variance and expressed in percentage (Hanson et al., 1956).

Heritability values are classified as low, moderate and high according to (Robinson et al., 1949).

\section{Results}

Mean squares owing to various sources of variation on ten (10) traits viz., plant height, number of branches per plant, number of clusters per plant, number of fruits per cluster, number of fruits per plant, number of days to first flowering, number of days to first fruit set, fruit weight, number of locules, pericarp thickness and coefficient of variation were presented in Table 1.

The mean value of plant height was $49.31 \mathrm{~cm}$; number of branches had a mean value of 1.03 and 1.68 for number of clusters per plant. The mean value of number of fruits per cluster, number of fruits per plant, number of days to first flowering and number of days to first fruit set recorded was $26.79,3.23,56.13$ and 67.10 respectively. The mean value for fruit weight was 23.32g; 2.31 for number of locules and the mean value of pericarp thickness was $2.84 \mathrm{~mm}$. The variation due to genotype was significant for plant height, number of branches, number of clusters per plant, number of fruits per cluster, number of fruits per plant, number of days to first flowering, number of days to first fruit set, fruit weight and pericarp thickness at $5 \%$ probability levels. The variation due to genotype was non-significant for number of locules under study at $5 \%$ probability level.

Variation due to replication was also significant for number of branches per plant, number of clusters per plant, number of fruits per cluster, number of days to first flowering, number of days to first fruit set, fruit weight, number of locules and pericarp thickness at 5\% probability levels. Only plant height was non-significant under study at $5 \%$ level of probability. Coefficients of variation for all the traits were presented in Table 1. Number of clusters per plant, number of fruits per cluster, number of fruits per plant, fruit weight, number of locules, pericarp thickness, plant height had high coefficient of variation whereas number of branches had the highest coefficient of variation $(82.58 \%)$ while number of days to first flowering and number of days to first fruit set had low coefficient of variation values. 


\begin{tabular}{|l|l|l|l|l|l|l|l|l|l|l|l|}
\hline $\begin{array}{c}\text { Source of } \\
\text { Variation }\end{array}$ & DF & PH & NOB & NOCPP & NOFPC & NOFPP & NODFF & $\begin{array}{l}\text { NODFF } \\
\text { S }\end{array}$ & FW & NOL & PCT \\
\hline Genotype & 2 & $469.35^{*}$ & $2.61^{*}$ & $3.54^{*}$ & $2.33^{*}$ & $3.75^{*}$ & $149.29^{*}$ & $142.21^{*}$ & $168.8^{*}$ & $0.04^{\mathrm{ns}}$ & $3.05^{*}$ \\
\hline Replication & 3 & $44.72^{\text {ns }}$ & $2.37^{*}$ & $2.18^{*}$ & $0.33^{*}$ & $0.79^{\mathrm{ns}}$ & $29.02^{*}$ & $9.45^{*}$ & $49.8^{*}$ & $0.12^{*}$ & $0.19^{*}$ \\
\hline Error & 6 & 77.72 & 0.72 & 1.02 & 0.42 & 2.26 & 10.10 & 11.67 & 69.5 & 0.07 & 0.29 \\
\hline CV\% & & 17.88 & 82.58 & 60.38 & 26.79 & 46.61 & 5.66 & 5.05 & 35.8 & 11.5 & 19.0 \\
\hline Grand mean & & 49.31 & 1.03 & 1.68 & 26.79 & 3.23 & 56.13 & 67.60 & 23.32 & 2.31 & 2.84 \\
\hline
\end{tabular}

Table 1: Mean Squares and Coefficient of Variation on Quantitative Traits of Tomato

Note: *** Significant At 5\% And 1\% Respectively, Ns Is Not Significant. PH= Plant Height, NOB= Number of Branches/Plant,

NOCPP = Number of Cluster per Plant, NOFPC=Number of Fruits per Cluster, NODFF= Number of Days Tofirst Flowering, NODFFS= Number of Days to First Fruit Set, FW= Fruit Weight, NOL= Number of Locules, PCT=Pericarp

Variance components, phenotypic and genotypic coefficients of variation, heritability in broad sense and genetic advance estimated for ten quantitative traits were presented in Table 2.

- $\quad$ Plant height (cm): The GCV and PCV values were (20.07) and (26.99) per cent respectively. Heritability estimates was $55.75 \%$. Genetic advance estimate of $15.22 \%$ was obtained.

- $\quad$ Number of branches per plant: The GCV and PVC for number of branches per plant were (66.56) and (82.52) per cent respectively. Heritability of 39.49 percent was obtained. The genetic advance estimate was 0.89 percent.

- Number of clusters per plant: The GCV and PCV were (47.25) and (76.45) per cent respectively. The heritability estimate was 38.18 percent with a genetic advance estimate of 1.01 percent.

- Number of fruits per cluster: The coefficients of variability for genotypic and phenotypic were $2.59 \%$ and $3.52 \%$ respectively along with heritability estimate of $53.93 \%$ and a genetic estimate of $1.05 \%$.

- Number of fruits per plant: The GCV and PCV were (18.83) and (50.21) per cent respectively. The heritability estimate was $14.07 \%$ and genetic advance estimate of $0.47 \%$.

- Number of days to first flowering: The GCV and PCV values are (10.51) and (11.94) per cent respectively. Heritability estimate was $77.48 \%$ and genetic advance value of $10.69 \%$.

- Number of days to first fruit set: The coefficients of variability for genotype and phenotype were $8.45 \%$ and $9.85 \%$ respectively with heritability estimate of $73.66 \%$ and genetic advance estimate of $10.10 \%$.

- $\quad$ Fruit weight: The GCV and PCV obtained were 21.37 and 41.65 percent respectively. The value of heritability was 26.32 percent and estimate of genetic advance was 5.27 per cent.

- Number of locules: The coefficient of variability at the genotypic and phenotypic levels was $6.85 \%$ and $10.87 \%$ respectively. The heritability estimate was $11.90 \%$ and genetic advance estimate was $6.15 \%$.

- $\quad$ Pericarp thickness (cm): The values $29.25 \%$ and $34.85 \%$ were obtained for GCV and PCV. $1.43 \%$ was recorded for genetic advance.

\begin{tabular}{|c|c|c|c|c|c|c|}
\hline Traits & Vg & Vp & GCV & PCV & $\mathbf{h}^{2}$ & GA \\
\hline Plant height (cm) & 97.91 & 175.63 & 20.07 & 26.99 & 55.75 & 15.22 \\
\hline Number of branches & 0.47 & 1.19 & 66.56 & 82.52 & 34.49 & 0.89 \\
\hline Number of cluster per plant & 0.63 & 1.65 & 47.25 & 76.45 & 38.18 & 1.01 \\
\hline Number of fruits per cluster & 0.48 & 0.89 & 2.59 & 3.52 & 53.93 & 1.05 \\
\hline Number of fruit per plant & 0.37 & 2.63 & 18.83 & 50.21 & 14.07 & 0.47 \\
\hline Number of days to first flowering & 34.79 & 44.90 & 10.51 & 11.94 & 77.48 & 10.69 \\
\hline Number of days to first fruit set & 32.64 & 44.31 & 8.45 & 9.85 & 73.66 & 10.10 \\
\hline Fruit weight & 24.83 & 94.33 & 21.37 & 41.65 & 26.32 & 5.27 \\
\hline Number of locules & 7.15 & 0.06 & 6.85 & 10.87 & 11.90 & 6.15 \\
\hline Pericarp thickness & 0.69 & 0.98 & 29.25 & 34.85 & 70.41 & 1.43 \\
\hline
\end{tabular}

Table 2: Estimate of Genetic Parameters on Variance Components, Heritability in Broad Sense and Genetic Advance Key: $V_{g}$ : Genotypic variance, $V_{p:}$ Phenotypic variance, GCV: Genotypic coefficient of variance, PCV: Phenotypic Coefficient of variance, $h^{2}$ : Heritability, GA: Genetic Advance

The result of correlation studies for ten quantitative traits; fruit weight, number of locules per fruit, pericarp thickness, number of fruits per plant, number of fruits per cluster, number of days to first flowering, number of days to first fruit set were presented in Table 3.

- Fruit weight: This trait showed positive and highly significant correlation coefficients with pericarp thickness (0.902) and non-significant but positive correlation with number of locules (0.132) and number of fruits per cluster $(0.102)$ and also negative correlation with number of fruits per plant $(-0.132)$.

- Number of locules: Number of locules showed non-significant negative association with number of fruits per cluster (-0.313).

- Pericarp thickness: Pericarp thickness showed positive non-significant association with number of fruits per cluster (0.286), number of days to first flowering (0.193), number of days to first fruit set (0.226) and nonsignificant negative correlation with number of fruits per plant $(-0.247)$. 
- Number of fruits per plant: Number of fruits per plant showed negative association with number of days to first flowering $(-0.619)$, number of days to first fruit set $(-0.626)$, non-significant and negative association was reported in number of fruits per cluster $(-0.199)$.

- Number of fruits per cluster: It showed negative correlation with number of days to first flowering (-0.619) and non-significant negative correlation with number of fruits per cluster.

- Number of days to first flowering: The trait showed negative correlation with number of fruits per plant (-0.619)

- Number of days to first fruit set: This trait showed highly significant positive correlation with number of days to first flowering (0.960) and it showed significant negative correlation with number of fruits per plant $(-0.626)$.

\begin{tabular}{|c|c|c|c|c|c|c|c|}
\hline Traits & FW & NOL & PCT & NOFPP & NOFPC & NODFF & NODFFS \\
\hline FW & - & 0.132 & $0.902^{*}$ & -0.132 & 0.102 & -0.022 & -0.025 \\
\hline NOL & & - & -0.089 & 0.013 & -0.313 & 0.001 & -0.010 \\
\hline PCT & & & - & -0.247 & 0.286 & 0.193 & 0.226 \\
\hline NOFPP & & & & - & -0.199 & $-0.619^{*}$ & -0.626 \\
\hline NOFPC & & & & & - & 0.043 & -0.027 \\
\hline NODFF & & & & & & - & $0.960^{*}$ \\
\hline NODFFS & & & & & & & - \\
\hline
\end{tabular}

Table 3: Phenotypic Correlation on Yield Component Traits

*,** - Significant at 5\% and 1\% Level of Probability Respectively; FW-Fruit Weight, NOFPC-Number of Fruits Per Cluster, NOL-Number of Locules, NODFF- Number of Days to First Flowering, PCT-Pericarp Thickness, NODFFS- Number of Days to First Fruit Set, NOFPP- Number of Fruits Per Plant

\section{Cross Pollination among Tomatoes}

The results of cross pollination among three accessions of tomato, Akungba 1, Akungba 2 and NG/AA/SEP/09/042 were presented in the figure below:

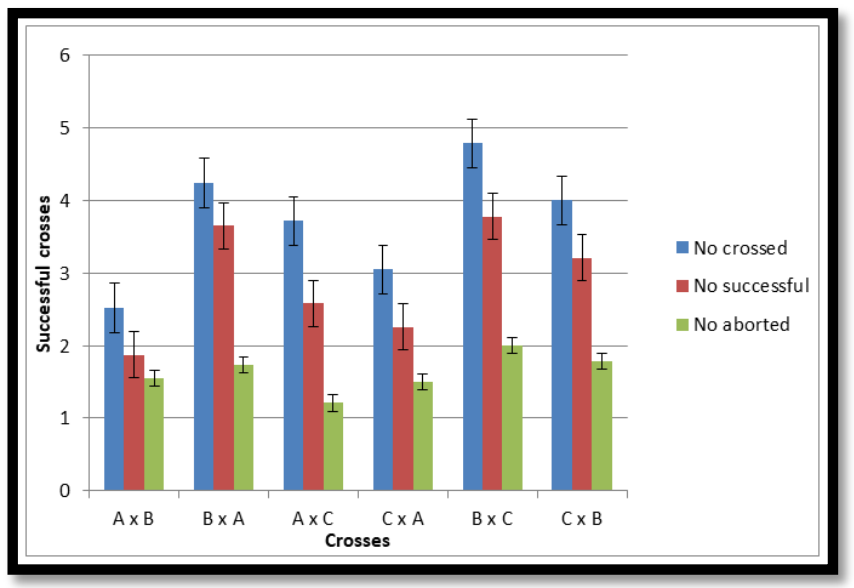

Figure 1: Cross combinations of the tomato genotypes

Where: $\mathrm{A}=$ Akungba 1, B = Akungba 2, C = NG/AA/SEP/09/042

\subsection{Akungba $1 \times$ Akungba 2}

Sixty (60) flowers were crossed with 43 successful crosses and 17 aborted. This makes the number of successful crosses to be statistically equal to $74.14 \%$ and aborted crosses equals $29.31 \%$.

\subsection{Akungba $2 \times$ Akungba 1}

One hundred and nineteen (119) flowers were crossed with 84 successful crosses and 33 aborted crosses. This makes the number of successful crosses equals $70.57 \%$ and the number of aborted crosses $27.73 \%$.

\subsection{Akungba 1 × NG/AA/SEP/09/042}

Ninety-three (93) flowers were crossed between A and C (Ax C), 62 crosses were successful and 23 crosses were aborted. $66.67 \%$ of the crosses were successful and $24.73 \%$ was aborted.

\section{4. $N G / A A / S E P / 09 / 042 \times$ Akungba 1}

In the cross between $\mathrm{C}$ and $\mathrm{A}(\mathrm{CxA}), 76$ flowers were crossed with 62 successful crosses and 23 successful crosses. $68.42 \%$ of the total cross was successful while $31.58 \%$ were aborted. 


\subsection{Akungba 2 × NG/AA/SSEP/09/042}

$77.04 \%$ of the cross between $B$ and $C(B x C)$ were successful while $24.04 \%$ were unsuccessful. The crosses were carried out between 115 flowers with 87 crosses successful and 28 crosses aborted. This is the most successful of all the crosses carried out.

\section{6. $N G / A A / S E P / 09 / 042 \times$ Akungba 2}

One hundred and four (104) flowers were cross between C and B (CxB), 77 crosses were successful while 25 were unsuccessful. $75.65 \%$ of the total crosses were successful while 24.35 were aborted.

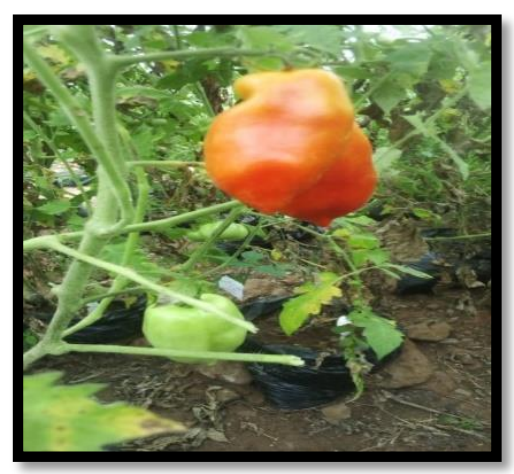

Figure 2: AKUNGBA 1

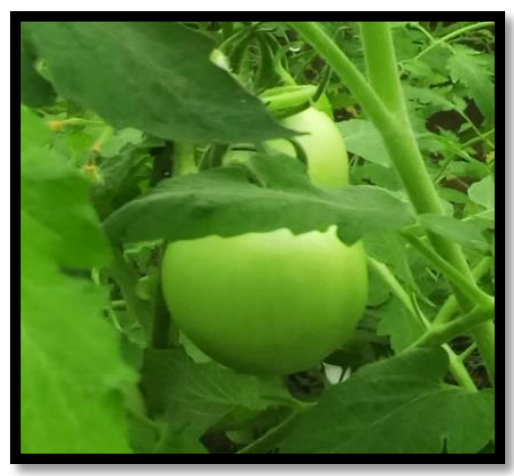

Figure 3: AKUNGBA 2

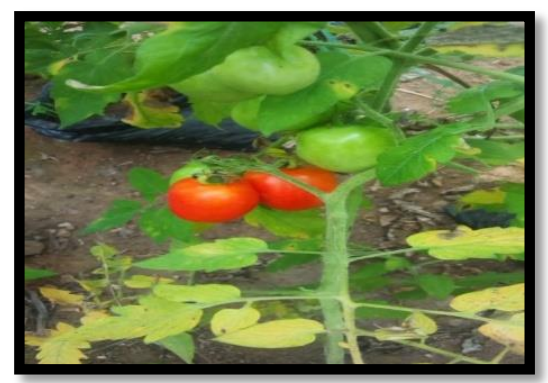

Figure 4: NG/AA/SEP/09/042

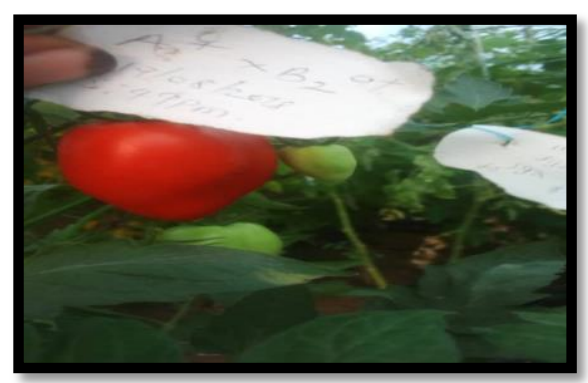

Figure 5: AKUNGBA 1 X AKUNGA 2 


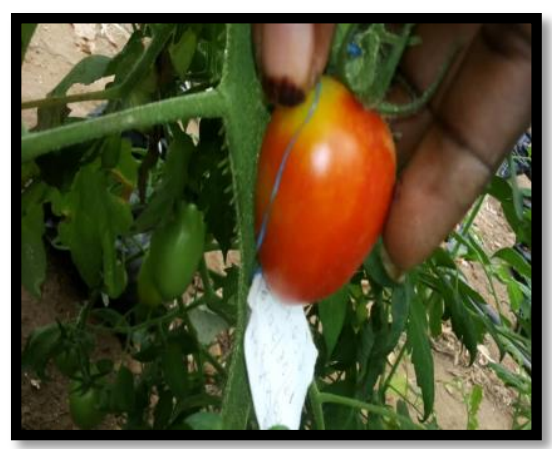

Figure 6: AKUNGBA 2 X AKUNGBA 1

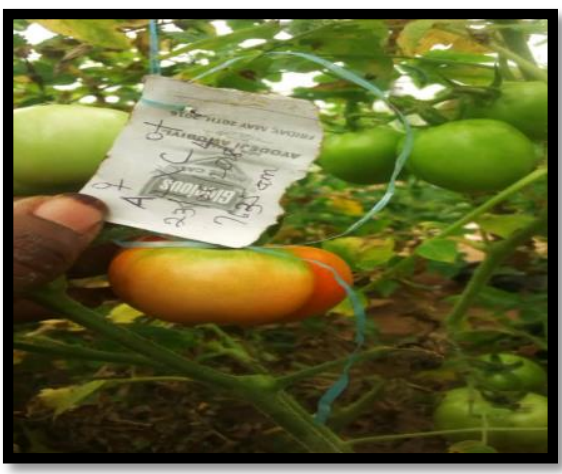

Figure 7: AKUNGBA 1 X NG/AA/SEP/09/042

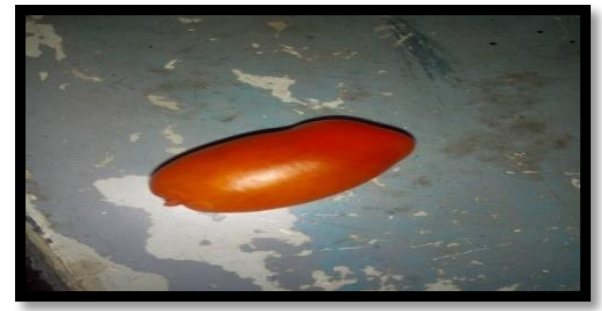

Figure 8: NG/AA/SEP/09/042 X AKUNGBA 1

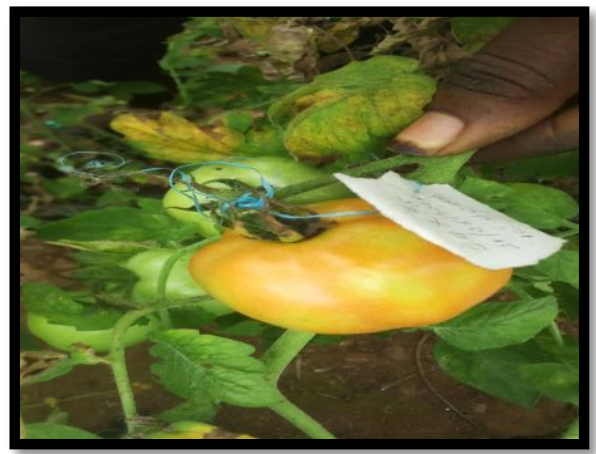

Figure 9: AKUNGBA 2 X NG/AA/SEP/09/042

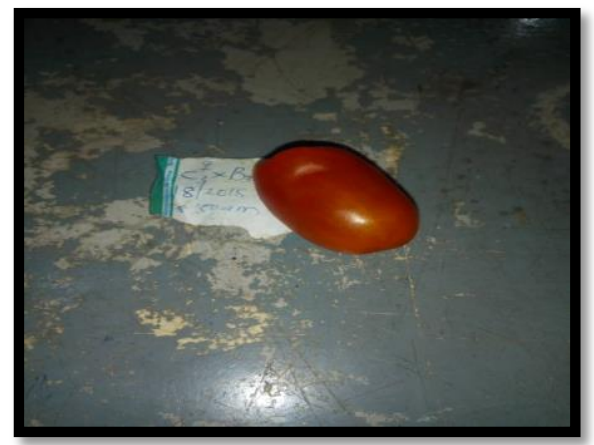

Figure 10: NG/AA/SEP/09/042 X AKUNGBA 


\section{Discussion}

In view of its importance, there is need to improve on the existing cultivated varieties in order to ensure the supply of good quality fruits and seed throughout the year. Because of the commercial importance of tomato, there is greatest need to develop new varieties with potential for high yield, quality and disease resistance characteristics. Cultivated tomatoes are self-pollinating. Pollen shedding often occurs before flower opens; therefore, the mode of reproduction is cleistogamy. Hybridization is important for the genetic improvement and breeding of tomatoes. Tomatoes are self-pollinating plants; therefore, emasculation of the male inflorescence from the female parent is indispensable. All wild tomato landraces can be crossed with the cultivated ones; this is useful because wild tomatoes are great source of desirable traits. Most commercial tomatoes are F1 hybrids, therefore seeds from them were produced by crossing two parent tomatoes (Kimura et al. 2008). A diallel cross is a mating scheme used by plant and animal breeders as well as geneticists to investigate the genetic underpinnings of qualitative traits. In full diallel, all parents are crossed to make hybrids in all possible combinations. Other types include half diallels with and without parents, omitting reciprocal crosses. Full diallels require twice as many crosses and entries in experiments, but allow for testing of maternal and paternal factors. In such a reciprocal cross, their effects are assumed to be negligible, and then a half diallel without reciprocals can be effective. Vegetable breeding is principally concerned with the improvement of both qualitative and quantitative plant characters. Hence, an adequate knowledge of genetics of various traits is very important in vegetable breeding programme for obtaining desired results. Usually, diverse plants are expected to give positive heterosis. Hence, it necessitates the study of genetic divergence among the existing varieties and germplasm collection for identification of parents for hybridization programme. The information of genetic divergence of various traits particular of those that contribute to yield and quality would be most useful in planning the breeding programme. Tomato is a unique vegetable crop, which is highly open to genetic improvement due to its high degree of homogeneity and ease of controlled pollination (Predeepkumar et al., 2001). Intense need is being felt to increase the bumper harvest of this crop due to increasing world population and consequently increasing consumption. (Ahmad et al., 2005) Crop improvement programme generally begins with the collection of germplasm from as diverse agro ecology as possible, followed by its proper evaluation and characterization. This requires careful analysis of variability present in the material by computing various parameters like PCV, GCV, heritability and correlation studies. The nature and extent of genetic variability is one of the most important criteria in formulating an efficient breeding programme and knowledge of phenotypic coefficient of variation (PCV) and genotypic coefficient of variation (GCV) is much helpful to predict the amount of variation in a given gathering of genotypes. The genotypic coefficient of variation (GCV) helps to measure the range of variation in the traits and provides a measure to contrast the genetic variability present in various characters.

In the present study, three genotypes were examined to know the quantity of variability for yield. The analysis of variance indicated significant differences amongst genotypes for all characters measured viz; plant height, number of branches per plant, number of clusters, number of fruits per cluster, number of fruits per plant, number of days to first flowering, number of days to first fruit set, fruit weight, number of locules, pericarp thickness. Measurement of variability parameters indicated that there is a lot of variation present among the genotypes studied. On the whole, the value of phenotypic coefficient of variation (PCV) was higher than the genotypic coefficient of variation (GCV) for all traits studied in the present findings, indicating the considerable influence of environmental factors on the performance of genotypes for different traits. Similar results were also reported in tomato by Premalakshmi et al., (2014), Rai et al., (2016), Kumar et al., (2017a) and Kumar et al., (2017b). In this research, the genotypic coefficient of variation and phenotypic coefficient of variation was high for plant height, number of branches, number of clusters per plant, fruit weight, pericarp thickness. Similar observations conform with findings made by Nandapuri et al., (1977), Reddy and Gulshanlal (1987), Kumar et al. (1980), Bangaru et al., (1983) and Natarajan (1992), Anandagowa (1977), and Mohanty (2002). Genotypic coefficient of variation and phenotypic coefficient of variation were low for number of fruits per cluster, number of days to first fruit set and number of locules whereas, moderate for number of days to first flowering and number of fruits per plant. Through heritability, we can understand the thought of the extents of genetic control for the expression of a particular trait and the consistency of phenotype in predicting its breeding value and the coverage of which a particular genetic character can be transmitted to the succeeding generations (Mangi et al., 2010). So, for the evaluation of relative extent of the effect of genes and environments on total phenotypic variability, heritability is very important. In this present research, heritability was high for number of days to first flowering, number of days to first fruit set and pericarp thickness. These observations noticed for this character is similar with result obtain by Dudi et al., (1983) and Arun et al., (2003). High heritability reported here clearly indicates that improvement of these traits in tomato can be obtained by means of simple selection. Heritability was moderate for plant height, number of branches per plant, number of clusters per plant, number of fruits per cluster. According to Sivaprasad, (2008), moderate to high heritability of these traits suggests that the environmental factors also play a key role in the expression of these traits. Therefore, improvement of fruit yield through its component traits should be on simple selection and also progeny tests. Number of fruits per plant, fruit weight and number of locules has low heritability indicating the role of the genotype by environment (G X E) interaction in the expression of these traits (Sivaprasad, 2008).

Yield is a complex unit associated with number of components traits. It is the chief concern of the plant breeders globally and is the ultimate factor on which selection programs are to be envisaged. All changes in yield must be accompanied by changes in one or more traits (Graffius, 1964). Correlation between two variables is a measure of association among the two variables. Correlation can be negative or positive. Both negative and positive correlation coefficients are important in plant breeding as the two shows the strength of association between any two characters under study. 


\section{Cross Combinations}

Using full diallel method of crossing, three accessions of tomato were crossed namely; Akungba 1, Akungba 2 and NG/AA/SEP/09/042 which were represented as A, B, C respectively. All parents were crossed and reciprocal crosses were made to make hybrids for all possible combinations. For example, A x B and its reciprocal cross B x A. The results showed varying characteristics of the hybrid obtained with the hybrid of A x B having a standard shape (Tomato- vegetable directory 2018) with less moisture content. B x A has a plum shape (Introduction to Roma Tomatoes) with more moisture content. A x C has less moisture content while $\mathrm{C}$ x A has more moisture content with a plum shape. B x $\mathrm{C}$ has a beefsteak shape with low moisture content whereas, $\mathrm{C} \times \mathrm{B}$ has a plum shape with high moisture content.

\section{Conclusion}

All the ten quantitative traits were significantly different from one another except for number of locules. The effect of replication was not significant on plant height and number of fruits for plant. The results show that the value of PCV was greater than GCV for traits. This implied that traits are influenced by the environment. Highly significant correlation exists between number of fruits per plant and number of clusters per plant. This implies that improving that trait would indirectly improve the number of fruits per plant and final fruit yield. Marketable size and weight with a beefsteak shape were observed in B x C and A x C. The F1 hybrid seeds will be planted in the next phase of the breeding programme for observation of segregation of genes into recombinant and parental types for appropriate selection process.

\section{Recommendation}

The F1 progeny is recommended for further evaluation on fruit quality traits and fruit yield.

Acknowledgement

This research was funded with the TETFUND Research Grants 2016 at the AdekunleAjasin University, AkungbaAkoko, Ondo State, Nigeria.

\section{References}

i. Allard, R. W. (1960). Principles of plant breeding. John Wiley and Sons, Inc., New York, USA Pp. 485

ii. Arun, J., Kohil, U. K. and Joshi, A., (2003). Genetic divergence for quantitative andqualitative traits tomato (Lycopersiconesculentum Mill.). Indian J. Agric, Sci., 73(2): 110-113

iii. Arunkumar, R. and V.Veeraragavathatham. (2005). Variability studies in certain

iv. Tomato (Lycopersiconesculentum. Mill.) genotypes under green house and open conditions indifferent seasons. South India Hort., 53(1-6): 18-24.

v. Burton, G. W., 1952, Quantitative interaction in grasses. In : proc. 6th Inter. Grassland Congr., 1 : $277-283$.

vi. Cobley, L.S. and W.M Steele. 1976. An Introduction to the Botany of Tropical Crops. Second edition. Longman Group Limited London.

vii. Cramer, C. S. and T.C. Wehner. 1998. Fruit yield and yield component means and Correlations of four slicing cucumber populations improved through six to tencycles of recurrent selection. J. Amer. Soc. Hort Sci. 123:388 $-395$.

viii. Dewey, D.R. and K.H. Lu. 1959. A correlation and path coefficient analysis of components of crested wheatgrass seed production. Agronomy Journal, 51:515 -518.

ix. Falconer, D.S. 1960. Introduction to quantitative genetics, Ronald Press Company, New York.Fiez, E.T., S.O. Norberg, and D.G. Jolliff. 1991. Yield components in threemeadowfoam lines. Agron. J. 83: 598 - 602.

x. Frankel, O.H. 1947. The theory of plant breeding for yield. Heredity. 1, 109 - 120.

xi. Graffius, R. 1964. A geometry for plant breeding. Crop Science, 4:241 - 246.

xii. Hanson, G.H., , H.F. Robinson, and R.E. Comstock. 1956, Biometrical studies of yield in segregating population of Korea lespedeza. Agron. J., 48: 268-272.

xiii. Haydar, A., M.A. Mandal., M.B .Ahmed., M.M. Hannan., R. Karim., M.A. Razvy., U.K. Roy, and M. Salahin. (2007). Studies on genetic variability and interrelationship among the different traits in tomato. Middle-East J. Sci. Res., 2(3-4): 139-142.

xiv. Joshi, A., Vikram, A. and Thakur, M. C., (2004). Studies on genetic variability, $\quad$ correlation and path analysis for yield and physio _ chemical triats in tomato (Lycopersiconesculentum Mil.). Progr. Hort., 36 (1): 51-58.

xv. Kneebone, W.R. (1956). Breeding for seedling vigor in sand blue stem ( Andropogonballi) and other native grasses. Agron. J. 48: 37 - 40.

xvi. Kumar, R., Muthukrishman, C.R. and Irulappan, I., (1980). Genetic variability, heritability and coheritability in the segregating generation of tomato. South IndianHort., 28: 105-108.

xvii. Kumar, R., Niraj Kumar, Jagadeesh Singh and Rai, G. K., (2006). Studies on yield and quality traits in tomato. Veg. Science., 33(2): 126-132.

xviii. Lungu, M. D. (1978). Classifying winter wheat environments into Adaptive zones as a basis for recommending a Reduction in the number of International Winter Wheat Performance Nursery Test sites. MSc dissertation. University of Nebraska. Lincoln. Department of Agronomy. U.S.A. Unpublished.

xix. Maribe, T. (1995). Advanced Trial of ARP Fresh Market Tomato lines. Africa Regional Program. Unpublished Report pages $81-85$.

xx. Mohanty, B. K., (2002). Studies on variability, heritability, interrelationship and path analysis in tomato. Ann. Agric. Res., 2 (1): 65-69. 
xxi. Mohanty, B. K., (2003). Genetic Variability, correlation and path coefficient studies in tomato. Indian J. Agric. Res., 37 (1): 68_ 71.

xxii. Naika, S., J.vanLidt de Jeude., M, de Goffau., M. Hilmi and B.van Dam. (2005).

xxiii. Cultivation of tomato : production, processing and marketing. CTA. Series no 17.

xxiv. Nandapuri, K. S., Kanwar, J. S. and Roshanlal, (1976). Correlation, path analysis and regression studies in tomato. Veg. Sci., 3: 37-40.

xxv. Nyirongo, M. K. (1995). Observational Trial of ARP Fresh Market Tomato lines. Africa Regional Program. Unpublished Report pages pp75 - 80 .

xxvi. Opena, R. T. and M. L. Kyomo (1990). Vegetable Research and Development in SADCC Countries: Proceedings of workshop held at Arusha, Tanzania, 9 - 13

xxvii. July 1990. AVRDC Publication No. 90 - 328.

xxviii. Osekita, O. S. and Ajayi, A. T. (2013). Character expression and selection differential for yield and its component in soybean (Glycine max (L.) Merril). Academia Journal of Agricultural Research. 1(9): 167 - 171.

xxix. Osekita, O.S. and Ademiluyi, A.T., (2014). Genetic advance, heritability and character association of component of yield in some genotypes of tomato (Lycopersiconesculentum Mill.). Acad. J. Biotechnol. 2(1):006-010.

xxx. Parvinder Singh, Surjan Singh, Cheema, D. S., Dhaliwal, M. S. and Singh, S., (2002). Genetic Variability and correlation study of some heat tolerant tomato genotypes. Veg. Sci., 29 (1): 68-70.

xxxi. Peirce, L. C. (1987). Vegetables characteristics, production and marketing. John Wileyand Sons. Inc. Toronto. Canada.

xxxii. Prashanth, S. J., (2003). Genetic Variability and divergence study in tomato (Lycopersiconesculentum Mill). M. Sc. (Agri) Thesis, Uni. Agric. Sci., Dharward (India).

xxxiii. Rani, I., D. Veeraragavathatham., and D. Sanjutha. (2008). Studies on Correlation and Path Coefficient analysis on Yield Attributes in Root Knot Nematodes Resistant

xxxiv. F1 Hybrids of Tomato. Journal of Applied Sciences Research, 4(3): 287 - 295.

xxxv. Reddy, M.L. and Gulshanlal, N. (1987). Genetic variability and path coefficient analysis in tomato (Lycopersiconesculentum Mill.) under summer season. Progr. Hort., 19 (3-4): 284-288.

xxxvi. Rice, R.P., L.W. Rice and H. D. Tindall. (1990). Fruit and vegetable production in warm climate. The Macmillan Press L.T.D. London and Basingstoke.

xxxvii. Robinson, H. F., Comstock, R. E. and Harvey, V. H., (1949). Estimates of heritability and degree of dominance in corn. Agron. J., 41: 353-359.

xxxviii. Rogler, G.A. (1954). Seed size and seedling vigor in crested wheat grass. Agron. J. 46:216 - 220.

xxxix. Shashikanth, B. N., Hosamani, R. M. and Pantil, B. C.(2010). Genetic variability studies in tomato (Solanumlycopersicon (Mill.) Wettsd. Karnataka J. Agric. Sci.23(3): 536 - 537.

xl. Singh, A.K and N. Raj. (2004). 'Variability studies in tomato under cold arid condition of Ladakh.' Hort.J., 17:67 72.

xli. Singh, H. N., Singh, D. K. and Gulshanlal, (2000), Variability pattern in Agromorphological characters in tomato (Lycopersiconesculentum Mill.) Pro. Hort., 32 (1): 79_81.

xlii. Singh, J.K., J.P. Singh, S.K. Jain, J. Aradhana and A. Joshi. (2002). Studies on genetic variability and its importance in tomato (Lycopersiconesculentum Mill.). Prog.Hort.,34:77 - 79.

xliii. Singh, R.K and B.D. Chaudhary. (2004). Biometrical Methods in Quantitative Genetics Analysis. Kalyani Publishers. New Delhi. India.

xliv. Sivaprasad, K. (2008). Genetic variability and correlation studies in bi-parental mating population of tomato (Solanumlycopersicon (Mill.) Wettsd). MSc dissertation.

xlv. University of Agricultural Sciences, Dharwad.

xlvi. Stevens, M. A. (1974). Varietal influence on nutritional value. P. 87 - 110. In P.L. Whiteand N.SELVEY (eds.) Nutritional qualities of fresh fruits and vegetables. Futura Publ. Co., Mt. Kisco, N.Y.

xlvii. Upadhyay, M.J.P. Singh., A. Singh and A. Joshi. (2005). Studies on geneticvariability in tomato (Lycopersiconesculentum Mill.). Prog. Hort. 37(2): 463- 465.

xlviii. Varela, A.M., A. Seif, and B. Lohr. (2003). A guide to IPM in tomato production inEastern and Southern Africa. CTA/ICIPE/GTZ.

xlix. Veershety, (2004). Studies on variability, character association and genetic diversity in tomato (Lycopersiconesculentum Mill.). M. Sc. (Agric.) Thesis, Uni. Agric. Science., Dharward (India). 